\title{
New Public Management and Accrual Accounting Basis for Transparency and Accountability in the Nigerian Public Sector
}

\author{
Dr Ofoegbu, Grace N.
}

\section{Introduction}

Accrual accounting is a basis of accounting where revenue is recorded when earned and expenditures recorded when its benefits are consumed. This basis of accounting is practiced in the private sector but introduction of the New Public Management (NPM) initiative has made it part of financial management improvement programme in the public sector (Shaw, 1999). New Public Management (NPM) is the application of private sector management approaches and techniques to public sector management. In recent years, some governments all over the world embraced the NPM and engaged in various reforms including financial management reforms which are gradually and steadily shifting them from traditional cash basis accounting practice to accrual accounting basis (Iyika, 2011). These financial reforms were triggered off by the desire to eliminate waste, inefficiency, poor service delivery, overspending, lack of accountability, transparency and improve quality of service delivery in the public service. The New Public Management (NPM) initiative was founded in the UK in 1979 and by the year 1991, it become a major reform strategy which was adopted by many countries all around the world and practiced by most member states of the Organization for Economic Cooperation and Development (OECD) (Shaw, 1999). The aim of the New Public Management initiative is to measure efficiency, and to facilitate competition with the private sector (Wynne, 20I1). The initiative is supported by the issuance of IPSAS accrual accounting standards by the IPSASB.

The situations that gave rise to the introduction of NPM in the U.K. and other developed countries of the world where NPM was first adopted were manifest in the African sub-region where the debate for good governance started in the late 1980' and subsequently resulted to adoption of new approaches to public sector management reforms (United Nations Economic Commission for Africa $\{$ UNECA $\}, 2003$ ). There are empirical evidences to show that there is lack of accountability and transparency in the Nigerian public sector. For instance government officials cannot take responsibility for their decisions and actions, corrupt practices are widespread, government business is not transacted in an open manner, financial reports are not prepared at the right time and budgets are prepared on cash basis. These led to introduction of public sector financial reforms in 2003 by President Obasanjo administration. Nigeria adopted International Public Sector Accounting Standards (IPSAS) cash basis of accounting as a foundation for migration into accrual basis accounting. The benefit of using accrual accounting is that it enhances accountability and transparency (Beech, 2007). This was in anticipation that the use of accrual-based accounting through the adoption and implementation of International Public Sector Accounting Standards (IPSASs) will promote greater transparency and accountability in public sector finances and allows for enhanced monitoring of government debt and liabilities for their true economic implications (IFAC Policy Position, 2012).

\section{Statement of Problem}

The reforms for effective accounting and financial reporting in Nigeria include adoption of IPSAS bases of accounting. IPSAS cash basis was adopted first in 2010 with December 2012 as deadline for issue of first published IPSAS's compliant financial statements and in preparation for migration to the accrual basis in 2015. However, the cash basis adoption was later shifted to January 2014, and accrual basis to January 2016.

However, people have doubted whether the adoption and implementation of accrual accounting method will yield the benefits of transparency, accountability and improvement of quality of accounting information. This doubt emanate from the fact that several attempts have been made in the past to improve on the financial reporting system of the Nigerian public sector but all met with failure.

This research was therefore designed to ascertain the accounting experts' perception on the implementation of IPSAS accrual basis of accounting in achieving transparency, accountability and improved quality of accounting information in the Nigerian public sector.

\section{Objective of the study}

This paper has been designed to:

1. Ascertain whether the adoption and implementation of IPSAS accrual basis of accounting will improve accountability in the Nigerian public sector financial reporting. 
2. Ascertain whether the adoption and implementation of IPSAS accrual basis of accounting will improve transparency in the Nigerian public sector financial reporting.

3. Ascertain whether the adoption and implementation of IPSAS accrual basis of accounting will enhance quality of accounting information in the Nigerian public sector financial reporting.

\section{Research Hypothesis}

1. Adoption and implementation of IPSAS accrual accounting in Nigeria will significantly improve accountability in the Nigerian Public Sector financial reporting.

2. Adoption and implementation of IPSAS accrual accounting in Nigeria will significantly improve transparency in the Nigerian Public Sector financial reporting.

3. Quality of financial information will be significantly improved with the introduction and implementation of IPSAS in the Nigerian public sector financial reporting.

\section{Significance of Study}

The significance of this study lies on the fact that the outcome will help to build the government confidence or otherwise in the action taken to adopt IPSAS accrual basis of accounting thereby encouraging the preparers of public financial report to put their full weight on the implementation in the new date of 2016. The study is also significant in the sense that the government will be encouraged by its outcome to do everything possible to ensure that adequate preparation is made between now and 2016 when accrual basis of accounting will be put in place. Any problems identified would be taken adequate care of before the implementation of the system. Moreover, this study is significant in the sense that it would help to build up literature on the assessment of the ability of IPSAS accrual accounting implementation in Nigerian to achieve the desired financial reporting objectives of accountability, transparency and improvement of quality on financial information.

\section{Scope of Study}

The scope of this study is the Nigerian public sector which includes the Federal, States and Local Governments. Government parastatals are not included. Only accountants in academia, government establishments, and auditors in public institutions and private firms constitute the respondents to the questionnaire administered. The variables being assessed are accountability, transparency and quality of financial information.

\section{Conceptual Framework}

\section{Review of Related Literature}

\section{New Public Sector Management}

The New Public Management describes a management practice that lays emphasis on centrality of citizen or customer centered activities as well as accountability for results (UNECA, 2003). It involves structural, organisational and managerial changes in the public service and application of a number of management techniques and practices that are mainly borrowed from the private sector and it is increasingly becoming a global phenomenon (Larbi, 1999). It has replaced the traditional public administration and the old model of organisation and public services delivery that were based on bureaucratic principles. The emphasis of NPM is on market-based public service management or enterprise culture focusing on output and performance measurement rather than input, results rather than procedures. Output is concerned with what the managers actually achieve with the resources available (Promberger, 2003). Introduction of performance measurement compels managers to focus on their specific responsibilities and carry out their tasks effectively and efficiently. It will also enable public sector bodies to be held directly accountable for their activities. The key elements of NPM according to Larbi (1999) include increasing use of markets and competition in the provision of public services, increasing emphasis on performance, outputs and customer orientation. The overall objective of NPM revolves around making public sector organisations more economically efficient and more accountable for performance to the public they serve (UNECA, 2003). The methods and programmes of the New Public Management are aimed at reforming the organisation and processes of the public sector to make it more competitive and efficient in resource use and service delivery (Promberger, 2003).

The New Public Management emphasis is that the private sector style of management practices should be applied in the public sector to increase flexibility in decision making (Hood, 1991). It is a shift to greater competition with the private sector and discipline in resource allocation in the public sector. The basic foundation of the NPM movement is the drive for efficiency and the use of the economic market as a model for political and administrative relationships (UNECA, 2003). The NPM reform overriding objectives in most of the countries are to improve efficiency and accountability in the conduct of public affairs and to facilitate competition with the private sector. It introduces competition in the public sector (through contracts and tendering) as rivalry is the key to lower costs and better standards (Hood, 1991 in UNECA, 2003). 


\section{Cash and Accrual Bases of Accounting}

Cash basis is a basis of accounting where only cash receipts and payments are recognised. Its advantage being that its operation is very simple, easy to learn and it reduces paper work. It allows for simple and unambiguous comparison between budgeted account and actual amount spent, hereby promoting control and accountability. Its major disadvantage is that it does not match expense with the revenue it generated (Adriana \& Alexandra, 2014). Even though there has been a wide call for a shift to accrual accounting especially since the introduction of the NPM, some authors still advocate for cash basis of accounting on the grounds that many governments have retained the cash basis of accounting. For instance Osmond (2009) opines that small municipalities that do not engage in numerous or large financial activities still need cash basis of accounting and may not require accrual accounting.

Accrual accounting on the other hand is an accounting basis where revenues and expenses are recognised according to the matching principle. The matching principle states that revenue and expenses are to be recognised in period that obligations are incurred or services performed (Foster, 2010). The accrual basis ensures that major capital assets are valued and the costs charged to the expenditure account over their useful lives through the use of some form of depreciation. The financial statements would include statement of income statement of financial position and statement of cash flow. The private sector style of financial statements provides additional information especially on the value of capital assets and allows increased comparability of relative efficiency between organisations. It results in greater management efficiencies and hence better outcomes for government and communities they serve. Improved accountability, better financial management and greater comparability of management performance result between years are achieved, an indication of the sustainability of government policy (Barrett 2004). Its disadvantages are that it is more difficult to understand than cash basis; it makes the net income not to be equal to the periods change in cash (Adriana \& Alexandra, 2014).

\section{Debates on Accrual Accounting in the Public Sector}

The worldwide call for a shift from cash basis to accrual accounting basis in the public sector organisations was a fall out of reforms in the public sector financial management otherwise called NPM. This pressure to change to accrual accounting emanated from International Monetary Fund (IMF), World Bank, Organization of Economic Co-operation for Development (OECD) and International Federation of Accountants (IFAC), Public sector Committee (Wynne, 2011), who shared the idea of NPM (Adriana \& Alexandra, 2014). It is believed that private sector based financial reporting system would enhance the transparency of government activities. Federation des Experts Comptables Europeans: FEE (2007) states that the implementation of accrual accounting should be one aspect of reforms under the New Public Management. Countries that have already adopted accrual accounting have generally been at the forefront for Public management reforms, setting Botswana as a case in point. It supplements cash accounting system to ensure that the financial information available to management is current, and provides meaningful analysis of resource usage within a department (UNECA, 2003).

There have been serious debates on whether accrual accounting would work in the public sector as it does in the private sector organisations. Many authors support the idea of introduction of accrual accounting in the public sector. For example, Osmond (2009) supports the idea by explaining that public sector entities engage in long-term contracts, in which payments are delayed, and using cash basis method may distort financial reports released to outside groups. The system provides a more accurate picture of what the organisation own and owes in economic terms. Foster (2010) maintains that the method has helped some governments such as Canada, New Zealand to make significant strides towards achieving their country's expenditure management program goals.

Contributing to the need for accrual accounting in government based organisations, Ball and Plugrath (2012) argues that cash basis of accounting cannot bring about transparency by government. It will only result in reporting merely part of the total picture of operations. The authors note that accrual basis of accounting enhances understanding of economic reality the effects of a set of decisions or actions on an organisation's assets and liabilities, revenues and expenses. UNECA, (2003) supports this idea by stating that accrual accounting supports effective and efficient decision-making by managers through capturing all or full costs associated with outputs produced. By this the managers are held responsible for all costs associated with the outputs produced, not only the immediate outlays.

Wynne, (2007) states that accrual accounting should not be considered in isolation but as part of reforms which have come to be known as New Public Management. The author asserts that countries using cash basis accounting should not change to accrual accounting except it is to accompany any financial reform within the overall public management reforms. Accrual accounting is not a purpose itself, rather a means of shifting the emphases of the budgeting system away from cash inputs towards outputs and outcomes (Wynne, 2007), a change of mentality on budget process by shifting from a rigid condition of cashed incomes and paid expenses 
to a situation where emphasis is on achievements and forecasts which may lead to increase of public management efficiency (Adrian \& Alexandra, 2014).

Wynne (2009) opines that the pressure to change to accrual accounting from IMF, World Bank, OECD and IFAC public sector committee has been misconstrued and that transition to accrual is often not a priority. The author argues that accrual accounting is not a modern approach to public sector accounting after all some city councils have practiced it for over 50years citing Birmingham city council as example. Moreover, the author argues that it is not a tried and tested approach but just a technical change made for political reasons, whereas cash accounting has a continued validity and the value of accrual is unproven. Talking about the role of accounts in public sector accountability, Wynne (2009) says that different reporting mechanisms and financial arrangement are required by different environments, what an organization should be concerned with is how accounting and financial management best improves the management of public services.

Hepworth (2011) argues that switching from cash to accrual basis would be time consuming and costly and there is no research evidence that such a switch would automatically produce benefits. In fact the doubt was equally expressed by Adrian \& Alexandra, (2014) as to whether the shift to accrual accounting in government was worth the cost and additional risks involved is increasing. A research funded by ACCA on the costs and benefits of introducing accrual accounting in Northern Island published in January 2006, revealed that even though the costs were perceived to be substantial, yet there was little evidence that the information from accrual accounting was extensively used in decision making. The author opines that unless the budget is also converted, reconciliation would be required each month. If the budget remains on cash, pressure on management is to manage cash, and so the key benefit is lost. In this circumstance preparation of revised forecasts is made more difficult.

\section{IPSAS adoption in the public sector}

Despite all these criticisms, the international Federation of Accountants (IFAC), International Public Sector Accounting Standards Boards (IPSASB) argues strongly that all governments should adopt the accrual basis. Even in the introduction to its cash basis accounting standard (2003), it states that the "committee encourages governments to progress to the accrual basis of accounting". In many of its other publications, it makes the case for transferring from the cash to the accrual basis. For instance the IFAC Policy Position, (2012) points out that the recent sovereign debt crisis, restructuring, defaults across the world were all caused by lack of transparency and accountability in governments, poor public financial management, and public sector financial reporting and the institutional deficiency for fiscal management in many countries. IFAC Policy Position 4 (2012) maintains that provision of accurate and complete information on expenditures and transactions is the only way to create trust between the governments and their constituents, demonstrate accountability and stewardship, and reinforce their own credibility. This type of high quality information can only be made possible through the adoption and application of accrual based accounting in the public sector. The information must be clear and comprehensive about the financial consequences of economic, political and social decisions taken by the governments. Moreover, the long-term impact of decision making must be the focus of the information.

All these arguments against and for prove that the move from cash basis to accrual accounting in the public sector financial reporting has not gained universal acceptance. For instance, the governments of Germany and Italy have not taken any definite stance on the issue. The government of Dutch has resisted the move saying that it would not adopt the accrual basis accounting. However, countries such as USA, Britain, China, India, Russia, Switzerland, South Africa, Brazil, Ghana, Rwanda, Uganda and Algeria have a project in place to adopt IPSASs accrual accounting as part of wider reforms (PricewaterhouseCoopers, 2009). Chile was recorded as the first state to introduce accrual accounting for the public sector in early 70's followed by New Zealand (Adriana \& Alexsandra, 2014). IPSAS are authoritative financial reporting and accounting standards issued by International Public Sector Accounting Standard Board for public sector entities all over the world for preparation of financial statements.

\section{Accrual Based Accounting for Accountability and Transparency}

IPSAS introduction was as a result of wide-spread pressure for greater government financial accountability and transparency (Chan, 2014). Accountability and transparency are two important elements of good governance that cannot be separated. Accountability implies being responsible for ones decisions or actions and giving explanations when asked to do so. Those who support adoption and introduction of accrual accounting in the public sector believe that accrual based accounting information and reporting would enhance accountability and transparency and would also help in improving good governance. Barrett (2004) describes it as a relationship based on obligations to demonstrate, review, and take responsibility for performance, both the results achieved in the light of agreed expectations and the means used. The public sector officials are stewards of national resources committed into their hands and they should be able to give explanations on how the 
resources were managed through performance reporting. In addition, Barrett (2004) emphasises that effective accountability requires much more than simply reporting performance, but involves evaluation, appropriate corrective actions and directly addressing likely consequences for individuals. Public service is accountable when it conducts the business of the government in an open, transparent and responsive manner. Accountability requires clear statement of goals while efficiency requires hard look at objectives (Hood, 1991).

Transparency on the other hand refers to the openness with which government business is conducted. It implies that people can clearly see the activities of government and understand what the government is doing. It requires openness which makes it easier for those outside the government to monitor and evaluate the performance of the government and its consistency with the policy intentions for fairness, propriety and sound stewardship. PricewaterhouseCoopers (2009) is of the opinion that adoption of IPSASs accrual accounting will improve accountability and ease the audit of public institutions. KPMG (2006) stresses that the current mixture of cash accounting and accrual accounting policies are no longer sufficient to achieve the goals set by governments. It then advocates development of new accounting policies along the line of full accrual accounting which would support the accountability and transparency goals set by stakeholders. The IFAC Policy Position (2012) states that:

Governments must implement the necessary institutional arrangements required to enhance public sector financial management transparency and accountability.

An integral and essential part of these arrangements is the use of accrual-based accounting-through the adoption and implementation of International Public Sector Accounting Standards (IPSASs) - which promotes greater transparency and accountability in public sector finances and allows for enhanced monitoring of government debt and liabilities for their true economic implications.

The IPSASs accrual accounting would represent a significant step forward in achieving the financial transparency of national governments world-wide (IFAC Policy Position, 2012).

\section{Reforms and Nigeria's Adoption of IPSAS Accrual Accounting}

The demand for good governance has triggered off the need for reforms in various sectors of the Nigerian economy. Good governance is evidenced in effective financial and human resource management through an improved budgeting, accounting and reporting, with emphasis on accountability, transparency and rooting out inefficiency particularly in public enterprises (World Bank, 2003 and 1992).

Nigeria's governance lacked in all these as the country was characterised by poor leadership with unlimited power, misuse of state resources, embezzlement, corruption, breakdown of law and order, to mention but a few. The country first embarked on various economic, institutional and financial reforms in 2003. The financial reforms demand that Government business should be transacted like in the private sector, in order to ensure transparency, accountability, efficiency and improved financial reporting and service delivery. The International Monetary Fund (IMF), World Bank and other International bodies interested in developing African countries are very much interested in these reforms triggered off by the NPM initiative. The New Public Management program has been embraced by the public sector of most countries of the world. It propagates that the accrual basis accounting should be introduced in the public sector as it is practice in the private sector and Nigeria has embraced accrual accounting in the public sector financial and budget reforms.

Considerable efforts have been made in the past by the Federal Government to standardise the financial statements produced by the Federal, States and Local governments. For instance, a committee was set up in 1984 to harmonise the manner of presentation of financial statement in the public sector discovered a great disparity existing between the accounts of Federal, States and Local governments in terms of statements and presentation formats. Hence, the committee recommended sixteen statements to be adopted by the three tiers of governments in the federation. The key recommendations were accepted and implemented, but the standard reporting formats were not uniformly adopted (Nyong, 2011). In 1998, another committee was set up in response to International Federation of Chartered Accountants exposure guidelines for government financial reporting, which proposed modified cash, modified accrual basis. The committee recommended adoption of accrual accounting and it was given a mandate to fashion out standard format for its application. The committee completed its work but the report was never considered by the Federation Accounts Allocation Committee (FAAC) for logistic or other technical reasons.

The global demands for transparency and accountability in public sector financial operations all around the world revealed greater inadequacies in the Nigerian financial reporting system. In 2006, the financial management unit of the World Bank South Asia Region developed a new diagnostic tool for the assessment of how well public sector accounting and auditing practices accord with the IFAC and International Organization of Supreme Audit Institutions (INTOSAI). The new diagnostic tool uses self-assessment questionnaires to identify the gaps in the national standards implementation in cash accounting basis. This was applied in Nigeria in collaboration with the South Asia Government Accounting Standard Adversary Board (SASAB) and Exposure Draft Report issued in Dec. 2009 at the instance of the International Development Association under 
the Economic Reform and Governance Project (ERGP). The study was carried out to actually identify the gap between the accounting and reporting practice of the Nigerian government sector and the provision of the IPSAS. The result indicated that differences exist between the existing practice and IPSAS basis accounting (Dankwambo, 2010). The cash basis accounting and the financial reporting system being practiced by the Nigerian public sector were not IPSAS cash basis compliant. The existing financial reporting practice was based on laws and regulations \{eg. Audit Ordinance, 1956 No 38 and Finance (Control and Management) Act 1958 N0 33$\}$ and does not accord with IPSAS cash basis of accounting.

The differences observed included the understated:

- all cash receipts, cash payments and cash balances of entities controlled by Federal Government were not included in the consolidated financial statement;

- external grants were not reflected in the financial statements of the federal government;

- Gaps on the disclosure requirements, adjustment of errors relating to prior year on the beginning cash balance, and finally

- Late submission of financial reports (Dankwambo, 2010).

The report then recommended implementation of IPSAS cash basis accounting and financial statements as precondition for transition to accrual accounting. The report also recommended a Nigerian version of IPSAS accrual basis since full accrual reporting system would impose some problem (Iyika, 2011). The standards address specific issues such as: the form, content and presentation of financial statement of government entities, the disclosure requirements, and the accounting treatments of different transactions.

The federal executive council (FEC) approved the adoption of IFRS and IPSAS in July 2010 for private and public sector respectively marking a real beginning of IPSAS adoption process. The IPSAS adoption is considered a road map to improving value of public entities financial reporting and is expected to lead to presentation of fair view of public finance and audit towards achieving good governance.

\section{Actions take to realize the objectives of the adoption include:}

- development of new charts of accounts by the Accountant General of the Federation which focuses on accrual basis of accounting (Anetie, 2011).

- organized workshops and seminars held in 2011 for Directors-General, Auditors-General, AccountantsGeneral, Directors of finances, Directors of Audit, Financial officers, Chief Accountants and other key officers of the government and regulatory institutions by various bodies such as the Financial Reporting Council of Nigeria (FRCN), the Board of the Public Finance Management Faculty of ICAN for Chartered Accountants in the public service, private sector and other interested stakeholders. These seminars were organised to sensitise the stakeholders on the adoption of IPSAS, and the challenges.

- lectures organized in 2012, by FRCN for stakeholders in preparation for implementation of IPSAS.

\section{Deadline for Adoption of IPSAS}

The original dates set for December 2012 as deadline for the adoption of IPSAS in Nigeria (Otunla, 2012) and 2013 for adoption of accrual accounting have failed. New dates of 2014 for cash basis and 2016 for accrual have been rescheduled.

\section{Research Methodology}

A survey design method was adopted in this work because the study involves an investigation of people's opinion or other manifestation through direct questioning. Data was collected from both primary and secondary sources. Primary data was collected through questionnaire prepared on 5 licker scale and administered to 112 respondents comprising Auditors, Accountants in the public sector and those in academics in the South Eastern Nigeria who possess adequate knowledge of both accrual and cash bases of accounting. The questionnaire sought to obtain the respondents' opinion on the anticipated benefits of the adoption and subsequent implementation of IPSAS accrual basis accounting in the Nigerian public sector with special emphasis on accountability, transparency and quality of accounting information. Out of the 112 questionnaire administered, 100 were returned and analyzed. The respondents were made up as follows: auditors $22 \%$, accountants in the public sector $68 \%$ and accountants in academia $10 \%$.

Secondary data was obtained from text books, journals, published and unpublished research materials, internet articles. Libraries and internets were made use of. Data collected were presented using frequency tables, percentages, bar charts, and pie charts. In testing the hypotheses, Special Package for Social Science (SPSS) was used. The test statistics used were standard deviation, mean, descriptive statistics and Friedman's test statistics. 
Comparing the calculated chi-square result of 23.545 against the critical chi-square result of 7.8147 (see tables 1, and 2) the calculated chi-square result is greater. Also, the p-value of 0.000 is less than 0.05 . These results are similar to the results in the descriptive and ranking tables, which show that the mean responses (with due consideration of the respective standard deviations) are within the same range. Thus this study reveals that the adoption and implementation of IPSAS accrual accounting in Nigeria will significantly improve accountability in the Nigerian Public Sector.

\section{Hypothesis Two}

The calculated chi-square result of 15.398 was compared against the critical chi-square result of 7.8147 (as shown in tables 3, and 4) and the calculated chi-square result is greater. Also, the p-value of 0.002 is less than 0.05. These results are similar to the results in the descriptive and ranking tables, which shows that the mean responses (with due consideration of the respective standard deviations) are within the same range. This study reveals that the adoption and implementation of IPSAS accrual accounting in Nigeria will significantly improve transparency in the Nigerian Public Sector.

\section{Hypothesis Three}

The calculated chi-square result of 8.149 was compared against the critical chi-square result of 7.8147 (as shown in tables 5, and 6), the calculated chi-square result is greater. Also, the p-value of 0.037 is less than 0.05 . These results are similar to the results in the descriptive and ranking tables, which shows that the mean responses (with due consideration of the respective standard deviations) are within the same range. This study reveals that quality of financial information will be significantly improved with the introduction and implementation of IPSAS in the Nigerian public sector.

\section{Findings}

- This study reveals that the adoption and implementation of IPSAS accrual accounting in Nigeria will significantly improve accountability in the Nigerian Public Sector.

- Also adoption and implementation of IPSAS accrual accounting in Nigeria will significantly improve transparency in the Nigerian Public Sector.

- This study equally reveals that quality of financial information will be significantly improved with the introduction and implementation of IPSAS in the Nigerian public sector.

\section{Discussion on findings}

Even though the respondents indicated that implementation of IPSAS in the Nigerian public sector would significantly improve transparency but they pointed out challenges that may hinder the implementation and realization of the objective such as insincerity among the government officers, lack of professionals in the field, inadequate training of public accountants. Other challenges pointed out are heavy cost of implementation which will constitute a burden on the part of government; inconsistency and inaccuracy in recording financial transactions; laxity on the part of the public servants in generating accounting information and delay in capturing the new system; lack of independence by government managers. The balance between costs and benefits of introducing accrual account in the public sector, is still a subject of debates among practitioners and those in academia (Adriana \& Alexandra, 2014). The country is really preparing to transit to accrual accounting in 2016 but up till now financial statements are still in arrears. Information prepared a year or more after the end of the fiscal year has limited uses for decision making. Lack of infrastructure is another big challenge facing the implementation. IPSAS requires that ICT must be developed to drive the new system, government business needs to be automated and accounting system must be computerised. A lot of information tracking is required to be able to produce annual financial statement. Lacks of electricity and human resource development impose some big challenges. A bit of training was provided by the Financial Reporting Council of Nigeria (FRCN), implementation of accrual accounting requires a lot of training and retraining because IPSAS is completely new to the Nigerian public sector. Implementation may be hindered by lack of legal framework to support the adoption and implementation of IPSAS in Nigeria. The Nigerian Financial Regulations which is a set of rules guiding public expenditure in accordance with prevailing fiscal policies does not contain anything on IPSAS. This was reviewed last in 2006 before the adoption of IPSAS in 2011 and needs to be revisited in line with the requirements of IPSAS accrual accounting. Also the constitution of the Federal Republic of Nigeria needs some reviewed for implementation of IPSAS to ensure strict compliance. This will also help to keep the government officers on their toes to ensure that implementation is taken very seriously.

\section{Conclusion and Recommendations}


Poor governance characterized by corruption, embezzlement, wastage of government resources, lack of transparency and accountability in government business transactions ravaged the Nigerian public sector for many decades. The financial reporting system was based on local laws thus the constitution of the Federal Republic of Nigeria and the Financial Regulations. The financial reports produced during the period never achieved the government objectives of measuring performance and exhibiting accountability and transparency in management of government funds at all levels. Reforms introduced by the government in 2003 came as a result of the world-wide pressure to introduce private sector style of management to the public sector otherwise known as New Public Management (NPM). The zeal to reform the government financial reporting system really came on board in 2009 when a gap analysis was conducted to identify the differences between the IPSAS cash basis accounting and the existing reporting practice. Several differences discovered prompted the setting up of a sub-committee by the Federation Accounts Allocation Committee to work out the roadmap for the adoption of IPSAS in the 3 ties of government thus federal, states and local governments. Nigeria has adopted IPSAS cash and accrual bases of accounting. Cash basis is assumed to have started in January 2014 and accrual basis to start in January 2016. A lot of people still doubt whether the practice of accrual accounting in the Nigerian public sector will ensure accountability, transparency and improvement in our reporting system considering the attitude of Nigerian public officers going to handle the implementation. This study has help to allay this fear as the practitioners, public sector accountants, auditors and accountants in academia indicated that IPSAS accrual basis would guarantee accountability, transparency and improvement in financial reporting but with some challenges which are not different from what other countries that implemented IPSAS accrual accounting faced. It is also hoped that poor financial reporting in the public sector will be corrected through the system.

\section{Recommendations}

Based on the findings, the study therefore recommends as follows:

- The government should provide the legal framework for proper and effective implementation of IPSAS accrual basis of accounting in Nigeria. Efforts should be made to enshrine the requirements of IPSAS accrual basis into the appropriate regulatory systems such as the constitution of the Federal Republic of Nigeria and the Financial Regulations. By this the public officers and other stakeholders would know that the Federal Government is really set out for the implementation to work.

- The government should also ensure that curriculum of Nigerian tertiary institutions and universities are reviewed to include IPSAS requirements.

- All levels of Nigerian public sector as well as ministries, departments and agencies should prepare for transition to Accrual Basis of Accounting already adopted by the country because it will help the public sector to achieve transparency, accountability and improved the quality of financial information.

- There should be training and retraining of public sector accounting staff on IPSAS Cash and Accrual bases Accounting. This will certainly address the issue of lack of manpower on IPSAS requirements. Professionals in the private sector can assist in the implementation using experience gained from the private sector. Organizations like PriceWaterHouseCoopers, Akintola Williams Deloitte should be engaged to hold seminars and Workshops with the public sector institutions, which can also act as consultants on implementation of IPSAS and provide updates on recent changes.

- Accountants employed in the public sector can help others to understand the requirements and basic principles of accrual accounting. Accountants in private practice can also assist by serving as consultants on technical issue, thereby providing additional human resources for the transition.

- The Financial Reporting Council (FRC) as the regulatory authority should be allowed to exercise its full authority and there should be no interference from the government to ensure effective and efficient operation of the council. Government should also allow the public sector managers free hand to operate the new system.

11]. ACCA, (2011)," Accrual Accounting ", www.accaglobal.

[2]. Adams, R.A (2004), Public Sector Accounting and finances, Lagos; Corporation Published.

[3]. Adriana and Alexandra (2006), "Cash Versus Accrual Accounting in Public Sector", Social Science Research Network, http://papers/ssrm/com

[4]. Ball L. \& Plugrath G. (2012), Government Accounting Making Enron Look Good, World Economics Vol.13, No 1. January March

[5]. Barrett, P. (2004), "Financial Management in the Public Sector- How Accrual Accounting and Budgeting Enhances Governance and Accountability (CPA Forum)"; Australia, Australia Audit Office

[6]. Beechy H. (2007), "Does Full Accrual Accounting Enhance Accountability"? The Innovation Journal: the Public Sector Innovation Journal, Volume 12(3), 2007, article 4

[7]. CIPFA (2010)," Public Financial Management: A whole System Approach”, Volume 1, P5, The Chartered Institute of Public Finance and Accountancy.

[8]. Christianens, J, Windels, P, \& Vanslembrouck, S (2004) “Accounting and Management Reform in Local Authorities: A Tool for valuating Empirically the Outcomes"; Faculteit Economie, Universiteit Gant. 
New Public Management and Accrual Accounting Basis for Transparency and Accountability in ...

[9]. Delloitte Touche, Tohmatsn, (2012)," Public Governance and Accountability”, UK, Delloitte Global Services Limited

[10]. Ernst \& Young (2010), "Public Sector Accounting Reforms Under Way But Convergence Of Standards In Europe Remains A Challenge", London, Ernst \& Young Global Limited

[11]. FEE (2007), "Accrual Accounting in the Public Sector", Federation des Experts Comptables Europeans Finance Management Faculty (2011), "Adoption of International Public Sector Accounting Standards (IPSAS)", Institute of Chartered Accountants of Nigeria (ICAN) http://www.ican-ngr.org

[12]. Foster N. (2010), "How to Implement Accrual Basis Accounting in the Public Sector", eHow Financial Accounting Standards Board; http://www.ehow.com

[13]. Hepworth N. (2011)," Introductory accrual accounting in the Public Sector: Some introductory Remarks”, U.K., Chattered Institute of Public Finance and Accountancy (CIPFA).

[28]. Hood C. (1991), "A Public Administration for All Seasons", Public Administration Vol. 69,Issue 1, pp 3 - 19

[29]. IFAC (2009)," Introduction to International Public Sector Accounting Standards (IPSASs)", New York, PricewaterhouseCoopers

[30]. IFAC (2012), "Public Sector Financial Management Transparency and Accountability: The use of International Public Sector Accounting Standards" (IFAC Policy Position 4), New York, International Federation of Accountants

[31]. Iyika P.I. (2011)," The Adaptability of Accrual Accounting in the Public Sector" http://www.scribd.com

[32]. KPMG (2006), "Accountability and Transparency in the Public Sector", KPMG IPSAS pdf

[33]. Larby G. A. (2003), Overview of Public Sector Management Reform, United Nations Research Insititute for Social Development Discussion Paper 112, worldbank.org

[34]. NASB (2010), "Report of the Committee on Road Map to the Adoption of International Financial Reporting Standards in Nigeria", http://www.financialreportingcouncil.gov.ng

[35]. Nnopu M. (2009), “Accrual basis Accounting Vs Cash Basis Accounting"; U.S.A., Hellum Inc.

[36]. Nwachukwu I. (2012, March 6), "IPSAS Adoption ....Road to Improving Value of Public Entities Financials", Business Day, www.businessdayonline.com

[37]. Nyong C.E. (2010)," Institutionalizing IPSAS in the Nigeria Public Sector Accounting System", MCPE Lecture, Lagos, ICAN.

[38]. Nyong C.E. (2011), "Nigeria's Adoption of International Public Sector Accounting Standards (IPSASs): Issues and challenges", Lagos, ICAN Public Finances Management Faculty Seminar, May 2011.

[39]. Osibote O.I. (2011), "Transition from Cash Basis to Accrual Basis of Accounting by Governments", Lagos, the ICAN Public Finance Management Faculty Seminar.

[40]. Osmond V. (2009)," Cash Vs Accrual accounting in a Public Sector", www.ehow.co.uk,

[41]. Otunla, J. (2012), "Federal Government Sets December Deadline for IPSAS Adoption", Thisday live,http://www.thisdaylive.com

[42]. PriceWaterHouseCoopers (2009), Introduction to International Public Sector Accounting Standards (IPSAS), PriceWaterHouseCoopers Ltd

[43]. Shaw, P. R. (1999),"New Trends in Public Management in Health Applications in Developed and Developing Countries", Washington DC, USA, World Bank Institute.

[44]. United Nations Economic Commission for Africa (2003)," Public Sector Management Reform in Africa; Lessons learned"; Ethiopia, United Nations Economic Commission for Africa,

[45]. Development Policy Management Division; ECA/DPMD/PSM/TP/03/1

[46]. Wynne, A. (2011) “ACCA in Public Eye: News letter of the ACCA Public Sector” Network, a.wynne@accaglobal.com retrieved $25 / 07 / 2013$

[47]. Wynne, A. (2009), "Accrual Accounting for the Public Sector - in Need of a Re-think", http://www.Saige.co.za/index htm files/05\%20Wyr retrieved 26/07/2013

[48]. Wynne, A. (2004), "Is the Move to Accrual based accounting a Real Priority for Public Sector Accounting", ACCA. http://www2.accaglobal.com

[49]. Wynne, A. (2007), “Accrual Accounting”, http://essaybank.ukessays.com/sample.essarys Retrieved 26/07/2013

[50]. World Bank (1989) World Bank Development Report, Washington DC, World Bank.

[51]. World Bank (1992) Governance and Development, Washington DC, World Bank http://publications.worldbank.org/index.php/m

[52]. Yahaya, S. (2006)," Integrity and Accountability Reforms in Nigeria: ICPC in Perspective"; In- Country Senior Executive Seminar on Nigeria's Public Service Reform, Abuja, Bureau of Public Service Reforms

\section{APPENDIX}

\section{List of Tables}

Table 1:Friedman Test Ranks for Hypothesis One

\begin{tabular}{|c|c|}
\hline & Mean Rank \\
\hline $\begin{array}{l}\text { introduction of IPSAS accrual in Nigeria will bring about clear assignment of responsibility in the public sector } \\
\text { for accountability purposes }\end{array}$ & 2.25 \\
\hline $\begin{array}{l}\text { IPSAS accrual accounting will enable government managers to focus on their specific responsibilities and carry } \\
\text { out their tasks effectively and efficiently }\end{array}$ & 2.33 \\
\hline $\begin{array}{l}\text { application of IPSAS accrual based accounting ensure provision of meaningful analysis of resource usage in the } \\
\text { Nigeria public sector }\end{array}$ & 2.60 \\
\hline with IPSAS accrual basis of accounting proper utilization of government resources will be enhanced & 2.83 \\
\hline
\end{tabular}

Table2: Friedman Test Statistics ${ }^{\mathrm{a}}$ for Hypothesis One

\begin{tabular}{|l|r|}
\hline $\mathrm{N}$ & 100 \\
Chi-Square & 23.545 \\
Df & 3 \\
Asymp. Sig. & .000 \\
\hline
\end{tabular}


New Public Management and Accrual Accounting Basis for Transparency and Accountability in ...

Table 3:Friedman Test Ranks for Hypothesis Two

\begin{tabular}{|l|r|}
\hline & Mean Rank \\
\hline private sector based financial reporting system would enhance transparency in government transactions \\
application of IPSAS accrual based accounting basis will ensure timely provision of accounting information in the \\
Nigeria public sector \\
with application of IPSAS accrual accounting there will be openness in transaction of government businesses \\
$\begin{array}{l}\text { application of accrual accounting in the Nigerian public sector will ensure that accounting information is promptly } \\
\text { provided for public to assess how the government is performing }\end{array}$ \\
\hline
\end{tabular}

Table 4: Friedmand Test Statistics ${ }^{\mathrm{a}}$ for Hypothesis Two

\begin{tabular}{|l|r|}
\hline N & 100 \\
Chi-Square & 15.398 \\
Df & 3 \\
Asymp. Sig. & .002 \\
\hline
\end{tabular}

a. Friedman Test

Table 5:Friedman Test Ranks

\begin{tabular}{|l|r|}
\hline \multicolumn{2}{|l}{ Mean Rank } \\
\hline $\begin{array}{l}\text { application of IPSAS accrual basis of accounting in the Nigeria public sector will ensure accuracy in recording of } \\
\text { financial transactions } \\
\text { IPSAS accrual accounting basis will ensures more reliable accounting information in the public sector when applied } \\
\text { IPSAS will ensure adequate provision of accounting information in the Nigerian public sector } \\
\text { with IPSAS accrual accounting accurate record of revenue and cost in the Nigerian public sector will be guaranteed }\end{array}$ \\
\hline
\end{tabular}

Table 6: Friedman Test Statistics ${ }^{\mathrm{a}}$ for Hypothesis Three

\begin{tabular}{|l|r|}
\hline $\mathrm{N}$ & 100 \\
Chi-Square & 8.149 \\
$\mathrm{Df}$ & 3 \\
Asymp. Sig. & .037 \\
\hline
\end{tabular}

a. Friedman Test 